\title{
Recent advances in synthetic carbohydrate-based human immunodeficiency virus vaccines
}

\author{
Zhenyuan Wang ${ }^{1}$, Chunjun Qin ${ }^{1}$, Jing $\mathrm{Hu}^{1,2}$, Xiaoqiang Guo ${ }^{1}, \mathrm{Jian}^{\mathrm{Yin}}{ }^{1 凶}$ \\ 1. Key Laboratory of Carbohydrate Chemistry and Biotechnology Ministry of Education, School of \\ Biotechnology, Jiangnan University, Wuxi 214122, China \\ 2. Wuxi Medical School, Jiangnan University, Wuxi 214122, China
}

An effective vaccine for human immunodeficiency virus (HIV) is urgently needed to prevent HIV infection and progression to acquired immune deficiency syndrome (AIDS). As glycosylation of viral proteins becomes better understood, carbohydrate-based antiviral vaccines against special viruses have attracted much attention. Significant efforts in carbohydrate synthesis and immunogenicity research have resulted in the development of multiple carbohydrate-based HIV vaccines. This review summarizes recent advances in synthetic carbohydrate-based vaccines design strategies and the applications of these vaccines in the prevention of HIV.

\section{KEYWORDS vaccine; human immunodeficiency virus (HIV); glycoprotein; N-glycosylation; neutralizing antibodies}

\section{INTRODUCTION}

Human immunodeficiency virus (HIV) continues to be a major global public health issue, with more than 1.2 million acquired immune deficiency syndrome (AIDS)-related deaths occurring yearly (UNAIDS, 2015). In 2014, 2 million individuals were newly infected with HIV-1, and 36.9 million people were living with HIV-1 (UNAIDS, 2015). Combination antiretroviral therapy (cART) or highly active antiretroviral therapy (HAART) has been shown to reduce AIDS-related mortality and morbidity (de Goede et al., 2015). Although cART has the potential to dramatically prolong the life expectancy of HIV-infected individuals, it does not provide a cure; therefore, individuals receiving cART must continue therapy for their entire lives and must overcome issues associated with the side effects and high costs of therapy (Tongo and Burgers, 2014; de Goede et al., 2015). Moreover, cART may lead to the emergence of resistant mutants. Therefore, an effective HIV vaccine is still ur-

Received: 11 December 2015, Accepted: 2 March 2016,

Published online: 17 March 2016

$\triangle$ Correspondence:

Phone: +86-510-85328229, Email: jianyin@jiangnan.edu.cn

ORCID: 0000-0002-2284-1666 gently needed to prevent HIV infection and progression to AIDS.

Since the first use of a vaccine by Edward Jenner in 1796, the development of cell culture and recombinant DNA technologies has revolutionized vaccine design (Rodrigues et al., 2015). In the middle of the 20th century, attenuated and inactivated vaccines developed through animal cell culture became the most commonly used form of vaccination against viral infection. In the late 20th century, recombinant DNA technologies facilitated the development of subunit antiviral vaccines comprised of protein and/or DNA (Rodrigues et al., 2015). To date, vaccines have been successfully applied for eradication of several acute viral diseases, such as smallpox, poliomyelitis, and measles (Minor, 2015). However, the development of an HIV vaccine is more challenging for several reasons, including the absence of a single case of natural immunological protection against HIV infection and the marked genetic variability of HIV-1 (de Goede et al., 2015). Moreover, live attenuated forms of viruses and inactivated viruses, which are typically used in the development of many traditional vaccines, are not suitable for developing HIV vaccines for safety reasons (Tongo and Burgers, 2014).

Different HIV vaccine candidates have been tested in 
human clinical trials, including virus-like particles, peptides, naked DNA, and viral vectors (Ensoli et al., 2014). Ideally, a highly effective HIV vaccine would elicit broadly neutralizing antibodies (bnAbs) to prevent infection and/or stimulate effective cytotoxic T lymphocyte (CTL) responses to slow disease progression (Mann and Ndung'u, 2015). To date, most vaccination trials have failed to provide suppression of HIV replication and prevention of AIDS progression (de Goede et al., 2015). Moreover, human vaccination studies have failed to induce bnAbs that target the envelope glycoprotein of HIV, suggesting that antibody-dependent cellular virus inhibition may play a key role (de Goede et al., 2015). A useful focus for HIV vaccine development is the reverse vaccinology approach, in which vaccines are designed based on epitopes recognized by biologically active monoclonal antibodies (mAbs) (Mayr and Zolla-Pazner, 2015).

To date, dozens of bnAbs have been isolated from pa- tients exhibiting chronic HIV-1 infection (Figure 1) (McLellan et al., 2011; Pejchal et al., 2011; Walker et al., 2011; Julien et al., 2013; Kong et al., 2013; Blattner et al., 2014; Liu et al., 2015). HIV-1 envelope glycoprotein, which plays a key role in viral tropism and the membrane fusion process, is the only antigen accessible to bnAbs (Moulard and Decroly, 2000; Burton and Mascola, 2015). HIV-1 envelope glycoprotein, consisting of the exterior gp120 and the transmembrane gp41, can be presented to the human immune system in many forms: functional envelope trimers, nonfunctional and conformationally rearranged envelope protein, and envelope trimer after shedding of one gp120 and the gp41 stump (Burton and Mascola, 2015). Importantly, only functional envelope trimers can be available to elicit neutralizing antibody (nAb) response (Burton and Mascola, 2015). The five general targets of isolated bnAbs are 1) the gp120 variable loop1/2 (V1/V2) glycan (bnAbs: PG9, PG16), 2) the gp120 variable loop 3 (V3) glycan (bnAbs:

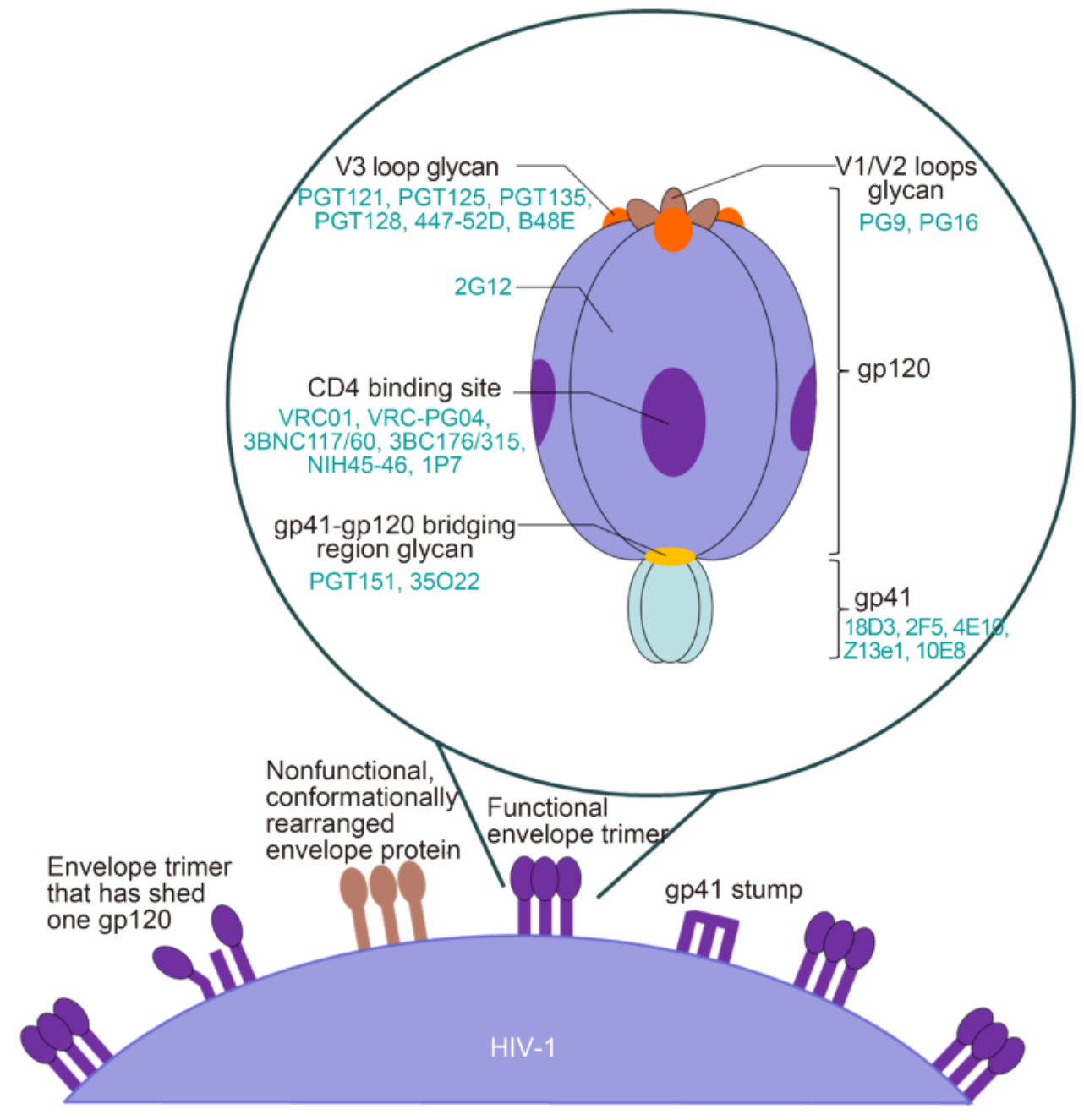

Figure 1. Schematic of the forms of HIV-1 envelope protein and the binding sites of broadly HIV-1-specific neutralizing antibodies. Below each bnAb site, the prototype antibodies that can bind at each site are listed. 
PGT121, PGT125, PGT135, PGT128, 447-52D, B48E), 3 ) the CD4-binding site on gp120 (bnAbs: VRC01, VRC-PG04, 3BNC117/60, 3BC176/315, NIH45-46, 1P7), 4) the gp41 membrane proximal external region (bnAbs: 18D3, 2F5, 4E10, Z13e1, 10E8), and 5) the gp41-gp120 bridging region glycan (bnAbs: PGT151, 35O22) (Crispin and Doores, 2015; Fernandez-Tejada et al., 2015b; Haynes, 2015; Liu et al., 2015). Thus, most bnAbs are directed toward HIV-1 envelope glycans, which have previously been considered a "glycan shield" that masks vulnerable epitopes on the surface of HIV (Fernandez-Tejada et al., 2015b). Although envelope glycans are added by the host cell machinery, the clustering of glycans can be arranged in a "non-self" pattern (Crispin and Doores, 2015). As glycosylation of viral proteins becomes better understood, the development of carbohydrate-based antiviral vaccines against special viruses has been considered as a potential strategy (Swarts and Guo, 2009).

All cells are thought to be coated with different forms of carbohydrates, including glycoproteins and glycolipids in eukaryotic cells and capsular polysaccharides and lipopolysaccharides in bacterial cells (HajiGhassemi et al., 2015). The exposure of cell-surface carbohydrates and their unique structures on diverse pathogens make them attractive vaccine targets (Morelli et al., 2011). Polysaccharides and glycoconjugates isolated from pathogens have been referred to as valuable antigens for vaccine development and have been used clinically against a range of infectious diseases, including Neisseria meningitidis, Streptococcus pneumoniae, and Haemophilus influenzae (Astronomo and Burton, 2010; Fernandez-Tejada et al., 2015a). However, the isolation of carbohydrates from biological material is a tedious process often resulting in low yields of oligosaccharide mixtures and is limited to organisms that can be cultured (Hecht et al., 2009). Thus, many researchers have focused on chemical synthesis of structurally well-defined oligosaccharides, which have been widely used in preparing vaccines designed to target bacteria, virus, parasites, and cancer (Nikolaev and Sizova, 2011; Cai et al., 2012; Alama et al., 2013; Anish et al., 2014; Cavallari et al., 2014; Deng et al., 2014; Horiya et al., 2014b; Qin et al., 2014; Danishefsky et al., 2015; Thompson et al., 2015). One of the most successful examples of synthetic carbohydrate-based vaccines is the Cuban vaccine against Haemophilus influenza type b (Hib), which provides protection comparable to that of licensed vaccines comprised of natural capsular polysaccharides (Hsu et al., 2011).

In this review, we focus on recent carbohydrate-based vaccine design strategies and their applications in HIV vaccination.

\section{ACCELARATION OF CARBOHYDRATE SYNTHESIS}

Regioselectivity and stereoselectivity are two major obstacles associated with approaching structurally welldefined oligosaccharides (Hsu et al., 2011). Despite ongoing challenges, tremendous progress in the preparation of chemically synthesized oligosaccharides has been achieved. Importantly, advances in glycochemistry, including protecting groups, linkers, solid supports, and glycosylation methods, have triggered the development of methods for automated carbohydrate synthesis (Seeberger, 2015). Over the past few decades, tremendous advances in automated oligosaccharide synthesis have facilitated the preparation of biologically important glycans (Seeberger and Werz, 2005; Hsu et al., 2011; Kröck et al., 2012; Eller et al., 2013; Seeberger, 2015). Plante and coworkers introduced an automated solidphase oligosaccharide synthesizer, which was initially adapted from a peptide synthesizer by addition of a reaction vessel allowing for temperature adjustments (Plante et al., 2001). Over the past 13 years, several generations of home-built systems have been refined, resulting in a commercial system, the Glyconeer 2.1 (Figure 2) (Seeberger, 2015). This synthesizer was found to increase the efficiency of glycosylation reactions, as shown by the synthesis of chains as long as 30-mers (Calin et al., 2013 ), and could produce a variety of carbohydrates, including glycosaminoglycans (GAGs) (Eller et al., 2013; Kandasamy et al., 2014) and glycopeptides (Hurevich and Seeberger, 2014). Recently, preparation of bacterial (Kandasamy et al., 2013) and plant glycans (Schmidt et al., 2015) has also been achieved using an automated oligosaccharide synthesizer. Thus, most techniques now available for solution-phase glycan synthesis can be carried out with an automated solid-phase oligosaccharide synthesizer (Seeberger, 2015).

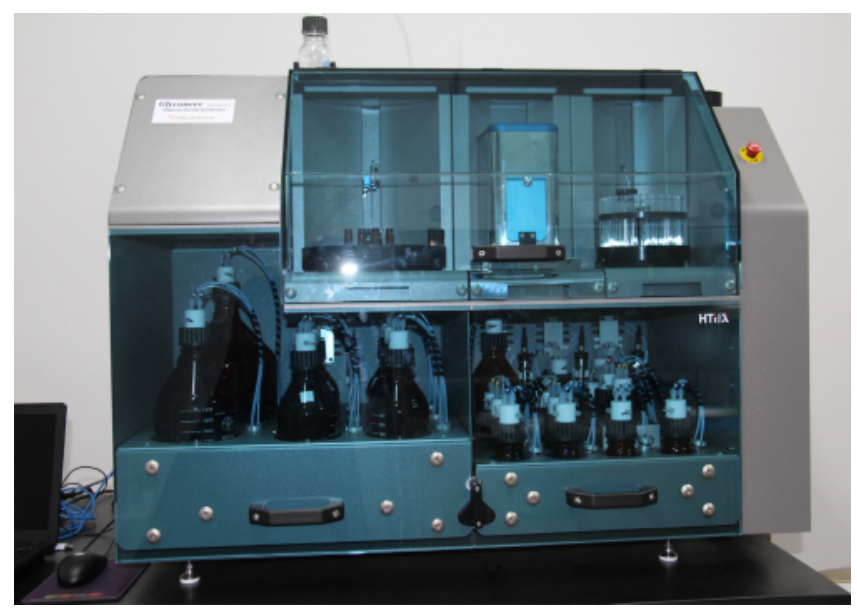

Figure 2. The first commercial "automated oligosaccharide synthesizer," Glyconeer 2.1. The first Glyconeer 2.1 in China was placed in Jiangnan University in 2015. 


\section{ENHANCMENT OF CARBOHYDRATE IMMUNOGENICITY}

The poor immunogenic response to carbohydrates is a major challenge encountered in the development of carbohydrate-based vaccines (Astronomo and Burton, 2010). Various methods have now been developed to overcome this serious problem. Major advances have been triggered by the discovery that protein-conjugated polysaccharides serve as T-cell dependent epitopes to acquire the requisite immunochemical ability (Roy and Chieh Shiao, 2011). These conjugates of B cell sugar epitopes and nonhomogeneous T-cell protein epitopes are considered semisynthetic carbohydrate vaccines (Peri, 2013). Recently, completely synthetic carbohydrate vaccines have been developed by replacing the nonhomogeneous protein with a homogeneous T-cell peptide epitope. Moreover, a single molecule assembled using different chemical units with various functions can be fully characterized by nuclear magnetic resonance (NMR) and mass and infrared (IR) spectroscopy (Peri, 2013).

Recently, the advantages of nanoparticle vaccines, including simultaneous antigen-loading, adjuvant codelivery, targeting properties, and increased circulation times, have triggered the development of glycosylated nanoparticle vaccines (Peri, 2013). Liposomes have been shown to be promising nanoparticles for multivalent display of synthetic carbohydrate epitopes, T-helper (Th) peptide epitopes, and adjuvants (Ingale et al., 2007; Said Hassane et al., 2009; Deng et al., 2014; Hu et al., 2015). Gold nanoparticles (GNPs) have also been intensively studied as carriers of carbohydrate vaccines (Safari et al., 2012).

\section{DESIGN AND APPLICATION OF CARBOHYDRATE-BASED HIV VACCINES}

In addition to the "self" pattern feature of viral glycans, variable glycosylation sites due to the constant mutation of the viral genome is another obstacle in the application of antiviral vaccines (Morelli et al., 2011). Despite this challenge, tremendous advances in the characterization of viral glycosylation have promoted the development of carbohydrate-based HIV vaccines. The first broadly neutralizing antibody isolated from infected individuals is IgG $2 \mathrm{G} 12$, which targets high-mannose glycans of gp120 (Hsu et al., 2011). Thus, the highly conserved high-mannose-type N-glycan clusters (Figure 3 ) of gp120 have become attractive targets in the development of HIV-1 vaccines to induce a robust immune response (Horiya et al., 2014b).

\section{G12-targeted vaccine design}

Biochemical studies have proposed that $\mathrm{Man}_{9} \mathrm{GlcNAc}_{2}$ and $\mathrm{Man}_{4}$ are two favorable targets of 2G12 (Adams et al., 2004; Wang et al., 2004; Calarese et al., 2005); thus, various new 2G12-targeted immunogens have been designed and constructed through the regioselective coupling of synthetic oligomannose with multivalent scaffolds (Wang, 2006). Some of these glycoconjugates are further attached to rationally designed peptide ( $\mathrm{Li}$ et al., 2005; Krauss et al., 2007; Wang et al., 2007; Joyce et al., 2008; Yang et al., 2010), carbohydrate (Wang et al.,

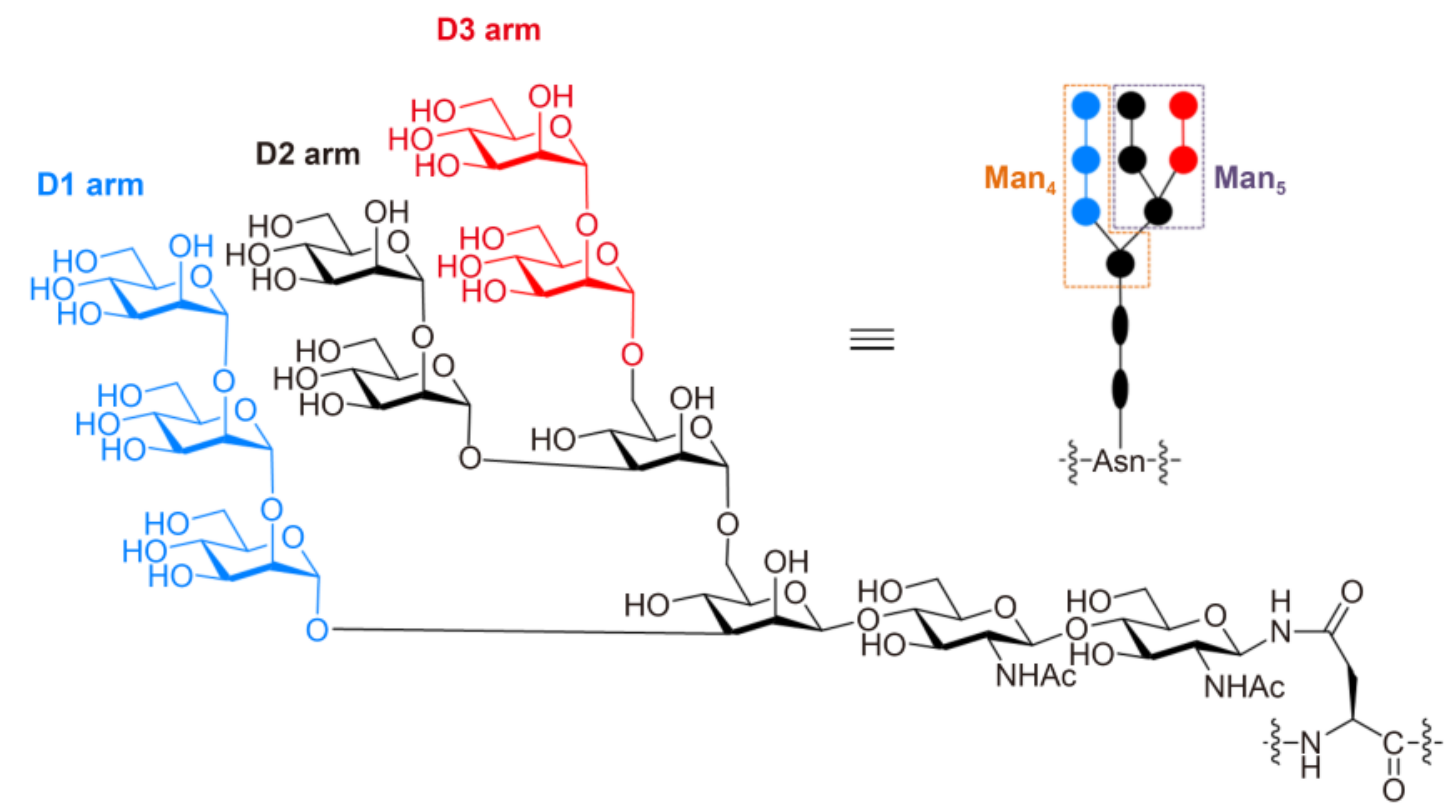

Figure 3. Chemical structure of high-mannose-type N-glycan $\mathrm{Man}_{9}(\mathrm{GlcNAc})_{2}$ and its branches D1, D2, and D3. 
2004; Ni et al., 2006), steroid (Li and Wang, 2004), peptide nucleic acid (Gorska et al., 2009; Ciobanu et al., 2011), dendrimer (Wang et al., 2008; Kabanova et al., 2010), and gold nanoparticle (Astronomo et al., 2008; Astronomo et al., 2010; Marradi et al., 2011) backbones and on biomacromolecules, such as $\mathrm{Q} \beta$ phage particles (Astronomo et al., 2010) and bovine serum albumin (BSA) protein (Astronomo et al., 2008). Most glycoconjugates have been shown to have weaker (at least 50 fold) $2 \mathrm{G} 12$ affinity compared to gp 120 . High $2 \mathrm{G} 12$ affinity can be obtained through presentation of a higher number of oligomannoses compared with the natural 2G12-gp120 interaction involving three or four glycans (Horiya et al., 2014b). In some cases, robust mannosebinding antibody responses were detected; however, none of these antibodies can bind to gp120 or neutralize HIV (Ni et al., 2006; Astronomo et al., 2008; Joyce et al., 2008; Astronomo et al., 2010; Kabanova et al., 2010). One possible explanation is that none of the tested glycoconjugates exactly mimic the epitope of $2 \mathrm{G} 12$. Thus, a particular arrangement of oligomannoses is necessary to construct gp120-like immunogens (Horiya et al., 2014b).

\section{Directed evolution of 2G12 epitope mimics}

Because there are just 3-4 oligomannoses in the $2 \mathrm{G} 12$ epitope of gp120 (Sanders et al., 2002; Scanlan et al., 2002; Calarese et al., 2003), it is necessary to synthesize constructs containing a similar number of oligomannoses. One new strategy is directed evolution of numerous random arrangements to highly antigenic glycoconjugates. Recently, both DNAs and peptides have been used as evolving scaffolds to develop oligomannose clusters (MacPherson et al., 2011; Temme et al., 2013; Horiya et al., 2014a; Temme et al., 2014). A library of $\sim 10^{13}$ multivalent $\mathrm{Man}_{9}$ presentations is created by chemically attaching glycans to $\sim 10^{13}$ DNA scaffolds contained alkyne. These sequences are then subjected to $2 \mathrm{G} 12$ affinity tests and polymerase chain reaction (PCR) amplification. Using this method, highly antigenic structures were obtained through several rounds of glycosylation and selection. DNA libraries provided selection of 3-4 glycan-containing structures that had gp120-like affinity for 2G12. In further studies (Horiya et al., 2014a), a system for multivalent glycopeptide evolution yielded glycopeptides with comparable $2 \mathrm{G} 12$ affinity to natural gp120. Although no immunological studies of these evolved constructs have been reported, the directed evolution method may provide a helpful basis for developing highly antigenic glycoconjugates.

\section{PG9- and PG16-targeted vaccine design}

PG9 and PG16, which show greater efficacy against HIV than 2G12 (Walker et al., 2009), are considered poten- tial targets for anti-HIV vaccine design. Recent synthetic studies have demonstrated that glycoconjugates containing complex glycans at N173 or N156 exhibit tight binding with PG9 (Horiya et al., 2014b). In another study, dimers of synthetic glycopeptides bearing only high-mannose $\left(\mathrm{Man}_{5} \mathrm{GlcNAc}_{2}\right)$ structures at both N156 and N160 positions were found to exhibit relatively tight binding with PG9. Notably, the dimeric $\mathrm{Man}_{5}$ construct also recognized the germline precursor of PG9, thereby showing the potential to initiate a PG9-like response (Alama et al., 2013). Saturation transfer difference (STD)-NMR and crystallographic studies of PG16 have shown that the sialic acid residues of complex glycans are important contributors to the overall binding strength (Pancera et al., 2013).

\section{Non-self sugar mimic vaccine}

D-Fructose has been reported to exhibit stronger 2G12gp120 complex inhibition than mannose. Doores and coworkers (2010) created a library of non-self sugars by modifying different positions of the terminal sugar of $\mathrm{Man}_{4}$ with different substitutions. They found that viruslike particles bearing these non-self sugars showed nanomolar affinities for $2 \mathrm{G} 12$. Although high titers of antibodies were elicited by non-self sugars containing constructs, no HIV-neutralizing antibody was observed (Doores et al., 2010).

\section{CONCLUSION}

In recent years, the biological role of $\mathrm{N}$-glycosylation of viral proteins has become better understood (Swarts and Guo, 2009). Although highly variable glycans are crucial for virus survival, some glycans with highly conserved structures are also essential for virulence, indicating that these highly conserved glycans may be utilized as targets for the development of vaccines and drugs (Swarts and Guo, 2009). To date, studies on synthetic carbohydrate-based antiviral vaccines have focused mainly on anti-HIV vaccines. The key challenges for achieving effective immunity using carbohydrate-based HIV vaccines are the design and construction of multivalent presentations of glycans for induction of several bnAbs and achieving a significant breadth of protection. Although much work is still needed to obtain effective carbohydrate-based HIV vaccines, the success of carbohydrate-based HIV vaccines can be forecasted on the basis of several facts, as follows: 1) the exposure of carbohydrates on the outer side of the HIV envelope glycoprotein enables these molecules to be accessible to the immune system; 2) a significant proportion of these glycans are highly conserved; 3 ) dozens of glycan-dependent HIV-1 bnAbs have been isolated; and 4) ad- 
vances in carbohydrate synthesis are expected to facilitate the development of vaccines free of contaminants. The latest attempts at developing a carbohydrate-based HIV vaccine utilizing reverse vaccinology approaches may also provide important insights into the development of carbohydrate-based vaccines against other viruses.

\section{ACKNOWLEDGMENTS}

We thank the National Science Foundation for Young Scientists of China (No. 21302068), the Natural Science Foundation of Jiangsu Province, China (No. BK20130127, BK20140154, and BK20150140), the Public Health Research Center at Jiangnan University (No. JUPH201502), and Key Laboratory of Carbohydrate Chemistry and Biotechnology Ministry of Education, Jiangnan University (KLCCB-KF201504).

\section{COMPLIANCE WITH ETHICS GUIDELINES}

The authors declare that they have no conflict of interests. This article does not contain any studies with human or animal subjects performed by any of the authors.

\section{REFERENCES}

Adams EW, Ratner DM, Bokesch HR, McMahon JB, O'Keefe BR, Seeberger PH. 2004. Oligosaccharide and glycoprotein microarrays as tools in HIV glycobiology; glycan-dependent gp120/protein interactions. Chem Biol, 11: 875-881.

Alama SM, Dennisona SM, Aussedatd B, Vohrad Y, Parkd PK, Fernández-Tejadad A, Stewarta S, Jaegera FH, Anastia K, Blinna JH, Keplere TB, Bonsignori M, Liao H-X, Sodroski JG, Danishefsky SJ, Haynesa BF. 2013. Recognition of synthetic glycopeptides by HIV-1 broadly neutralizing antibodies and their unmutated ancestors. Proc Natl Acad Sci U S A, 110: 18214-18219.

Anish C, Schumann B, Pereira CL, Seeberger PH. 2014. Chemical biology approaches to designing defined carbohydrate vaccines. Chem Biol, 21: 38-50.

Astronomo RD, Burton DR. 2010. Carbohydrate vaccines: developing sweet solutions to sticky situations? Nat Rev Drug Discov, 9: 308-324.

Astronomo RD, Kaltgrad E, Udit AK, Wang SK, Doores KJ, Huang CY, Pantophlet R, Paulson JC, Wong CH, Finn MG, Burton DR. 2010. Defining criteria for oligomannose immunogens for HIV using icosahedral virus capsid scaffolds. Chem Biol, 17: 357-370.

Astronomo RD, Lee HK, Scanlan CN, Pantophlet R, Huang CY, Wilson IA, Blixt O, Dwek RA, Wong CH, Burton DR. 2008. A glycoconjugate antigen based on the recognition motif of a broadly neutralizing human immunodeficiency virus antibody, $2 \mathrm{G} 12$, is immunogenic but elicits antibodies unable to bind to the self glycans of gp120. J Virol, 82: 6359-6368.

Blattner C, Lee JH, Sliepen K, Derking R, Falkowska E, Peña ATdl, Cupo A, Julien J-P, Gils Mv, Lee PS, Peng W, Paulson JC, Poignard P, Burton DR, Moore JP, Sanders RW, Wilson IA,
Ward AB. 2014. Structural delineation of a quaternary, cleavage-dependent epitope at the gp41-gp120 interface on intact HIV-1 Env trimers. Immunity, 40: 669-680.

Burton DR, Mascola JR. 2015. Antibody responses to envelope glycoproteins in HIV-1 infection. Nat Immunol, 16: 571-576.

Cai H, Huang ZH, Shi L, Sun ZY, Zhao YF, Kunz H, Li YM. 2012. Variation of the glycosylation pattern in MUC1 glycopeptide BSA vaccines and its influence on the immune response. Angew Chem Int Ed Engl, 51: 1719-1723.

Calarese DA, Lee HK, Huang CY, Best MD, Astronomo RD, Stanfield RL, Katinger H, Burton DR, Wong CH, Wilson IA. 2005. Dissection of the carbohydrate specificity of the broadly neutralizing anti-HIV-1 antibody 2 G12. Proc Natl Acad Sci U S A, 102: 13372-13377.

Calarese DA, Scanlan CN, Zwick MB, Deechongkit S, Mimura Y, Kunert R, Zhu P, Wormald MR, Stanfield RL, Roux KH, Kelly JW, Rudd PM, Dwek RA, Katinger H, Burton DR, Wilson IA. 2003. Antibody domain exchange is an immunological solution to carbohydrate cluster recognition. Science, 300: 2065-2071.

Calin O, Eller S, Seeberger PH. 2013. Automated polysaccharide synthesis: assembly of a 30mer mannoside. Angew Chem Int Ed Engl, 52: 5862-5865.

Cavallari M, Stallforth P, Kalinichenko A, Rathwell DCK, Gronewold TMA, Adibekian A, Mori L, Landmann R, Seeberger PH, Libero GD. 2014. A semisynthetic carbohydrate-lipid vaccine that protects against S. pneumoniae in mice. Nat Chem Biol, 10: 950-958.

Ciobanu M, Huang KT, Daguer JP, Barluenga S, Chaloin O, Schaeffer E, Mueller CG, Mitchell DA, Winssinger N. 2011. Selection of a synthetic glycan oligomer from a library of DNAtemplated fragments against DC-SIGN and inhibition of HIV gp120 binding to dendritic cells. Chem Commun (Camb), 47: 9321-9323.

Crispin M, Doores KJ. 2015. Targeting host-derived glycans on enveloped viruses for antibody-based vaccine design. Curr Opin Virol, 11: 63-69.

Danishefsky SJ, Shue YK, Chang MN, Wong CH. 2015. Development of Globo-H cancer vaccine. Acc Chem Res, 48: 643-652.

de Goede AL, Vulto AG, Osterhaus AD, Gruters RA. 2015. Understanding HIV infection for the design of a therapeutic vaccine. Part II: Vaccination strategies for HIV. Ann Pharm Fr, 73: 169-179.

Deng S, Bai L, Reboulet R, Matthew R, Engler DA, Teyton L, Bendelac A, Savage PB. 2014. A peptide-free, liposome-based oligosaccharide vaccine, adjuvanted with a natural killer $\mathrm{T}$ cell antigen, generates robust antibody responses. Chem Sci, 5: 1437-1441.

Doores KJ, Fulton Z, Hong V, Patel MK, Scanlan CN, Wormald MR, Finn MG, Burton DR, Wilson IA, Davis BG. 2010. A nonself sugar mimic of the HIV glycan shield shows enhanced antigenicity. Proc Natl Acad Sci U S A, 107: 17107-17112.

Eller S, Collot M, Yin J, Hahm HS, Seeberger PH. 2013. Automated solid-phase synthesis of chondroitin sulfate glycosaminoglycans. Angew Chem Int Ed Engl, 52: 5858-5861.

Ensoli B, Cafaro A, Monini P, Marcotullio S, Ensoli F. 2014. Challenges in HIV Vaccine Research for Treatment and Prevention. Front Immunol, 5: 417.

Fernandez-Tejada A, Canada FJ, Jimenez-Barbero J. 2015a. Recent Developments in Synthetic Carbohydrate-Based Diagnostics, Vaccines, and Therapeutics. Chemistry, 21: 10616-10628.

Fernandez-Tejada A, Haynes BF, Danishefsky SJ. 2015b. Designing synthetic vaccines for HIV. Expert Rev Vaccines, 14: $815-831$.

Gorska K, Huang KT, Chaloin O, Winssinger N. 2009. DNA-tem- 
plated homo- and heterodimerization of peptide nucleic acid encoded oligosaccharides that mimick the carbohydrate epitope of HIV. Angew Chem Int Ed Engl, 48: 7695-7700.

Haji-Ghassemi O, Blackler RJ, Martin Young N, Evans SV. 2015. Antibody recognition of carbohydrate epitopes. Glycobiology, 25: 920-952.

Haynes BF. 2015. New approaches to HIV vaccine development. Curr Opin Immunol, 35: 39-47.

Hecht ML, Stallforth P, Silva DV, Adibekian A, Seeberger PH. 2009. Recent advances in carbohydrate-based vaccines. Curr Opin Chem Biol, 13: 354-359.

Horiya S, Bailey JK, Temme JS, Guillen Schlippe YV, Krauss IJ. 2014a. Directed evolution of multivalent glycopeptides tightly recognized by HIV antibody 2 G12. J Am Chem Soc, 136: 5407-5415.

Horiya S, MacPherson IS, Krauss IJ. 2014b. Recent strategies targeting HIV glycans in vaccine design. Nat Chem Biol, 10: 990-999.

Hsu CH, Hung SC, Wu CY, Wong CH. 2011. Toward automated oligosaccharide synthesis. Angew Chem Int Ed Engl, 50: 11872-11923.

Hu J, Qiu L, Wang X, Zou X, Lu M, Yin J. 2015. Carbohydratebased vaccine adjuvants - discovery and development. Expert Opin Drug Discov, 10: 1133-1144.

Hurevich M, Seeberger PH. 2014. Automated glycopeptide assembly by combined solid-phase peptide and oligosaccharide synthesis. Chem Commun (Camb), 50: 1851-1853.

Ingale S, Wolfert MA, Gaekwad J, Buskas T, Boons GJ. 2007. Robust immune responses elicited by a fully synthetic threecomponent vaccine. Nat Chem Biol, 3: 663-667.

Joyce JG, Krauss IJ, Song HC, Opalka DW, Grimm KM, Nahas DD, Esser MT, Hrin R, Feng M, Dudkin VY, Chastain M, Shiver JW, Danishefsky SJ. 2008. An oligosaccharide-based HIV-1 2G12 mimotope vaccine induces carbohydrate-specific antibodies that fail to neutralize HIV-1 virions. Proc Natl Acad Sci U S A, 105: 15684-15689.

Julien JP, Sok D, Khayat R, Lee JH, Doores KJ, Walker LM, Ramos A, Diwanji DC, Pejchal R, Cupo A, Katpally U, Depetris RS, Stanfield RL, McBride R, Marozsan AJ, Paulson JC, Sanders RW, Moore JP, Burton DR, Poignard P, Ward AB, Wilson IA. 2013. Broadly neutralizing antibody PGT121 allosterically modulates CD4 binding via recognition of the HIV-1 gp120 V3 base and multiple surrounding glycans. PLoS Pathog, 9: e1003342.

Kabanova A, Adamo R, Proietti D, Berti F, Tontini M, Rappuoli R, Costantino P. 2010. Preparation, characterization and immunogenicity of HIV-1 related high-mannose oligosaccharidesCRM197 glycoconjugates. Glycoconj J, 27: 501-513.

Kandasamy J, Hurevich M, Seeberger PH. 2013. Automated solid phase synthesis of oligoarabinofuranosides. Chem Commun (Camb), 49: 4453-4455.

Kandasamy J, Schuhmacher F, Hahm HS, Klein JC, Seeberger PH. 2014. Modular automated solid phase synthesis of dermatan sulfate oligosaccharides. Chem Commun (Camb), 50: 18751877.

Kong L, Lee JH, Doores KJ, Murin CD, Julien JP, McBride R, Liu Y, Marozsan A, Cupo A, Klasse PJ, Hoffenberg S, Caulfield M, King CR, Hua Y, Le KM, Khayat R, Deller MC, Clayton T, Tien H, Feizi T, Sanders RW, Paulson JC, Moore JP, Stanfield RL, Burton DR, Ward AB, Wilson IA. 2013. Supersite of immune vulnerability on the glycosylated face of HIV-1 envelope glycoprotein gp120. Nat Struct Mol Biol, 20: 796-803.

Krauss IJ, Joyce JG, Finnefrock AC, Song HC, Dudkin VY, Geng X, Warren JD, Chastain M, Shiver JW, Danishefsky SJ. 2007.
Fully synthetic carbohydrate HIV antigens designed on the logic of the 2G12 antibody. J Am Chem Soc, 129: 11042-11044.

Kröck L, Esposito D, Castagner B, Wang C-C, Bindschädler P, Seeberger PH. 2012. Streamlined access to conjugation-ready glycans by automated synthesis. Chem Sci, 3: 1617-1622.

Li H, Li B, Song H, Breydo L, Baskakov IV, Wang LX. 2005. Chemoenzymatic synthesis of HIV-1 V3 glycopeptides carrying two $\mathrm{N}$-glycans and effects of glycosylation on the peptide domain. J Org Chem, 70: 9990-9996.

Li Hg, Wang L-X. 2004. Design and synthesis of a template-assembled oligomannose cluster as an epitope mimic for human HIV-neutralizing antibody 2 G12. Org Biomol Chem, 2: 483-488.

Liu H, Bi W, Wang Q, Lu L, Jiang S. 2015. Receptor binding domain based HIV vaccines. Biomed Res Int, 2015: 594109594117.

MacPherson IS, Temme JS, Habeshian S, Felczak K, Pankiewicz K, Hedstrom L, Krauss IJ. 2011. Multivalent glycocluster design through directed evolution. Angew Chem Int Ed Engl, 50: 11238-11242.

Mann JK, Ndung'u T. 2015. HIV-1 vaccine immunogen design strategies. Virol J, 12: 3-13.

Marradi M, Di Gianvincenzo P, Enriquez-Navas PM, MartinezAvila OM, Chiodo F, Yuste E, Angulo J, Penades S. 2011. Gold nanoparticles coated with oligomannosides of HIV-1 glycoprotein gp120 mimic the carbohydrate epitope of antibody $2 \mathrm{G} 12$. J Mol Biol, 410: 798-810.

Mayr LM, Zolla-Pazner S. 2015. Antibodies Targeting the Envelope of HIV-1. Microbiol Spectr, 3: AID-0025-2014.

McLellan JS, Pancera M, Carrico C, Gorman J, Julien JP, Khayat R, Louder R, Pejchal R, Sastry M, Dai K, O'Dell S, Patel N, Shahzad-ul-Hussan S, Yang Y, Zhang B, Zhou T, Zhu J, Boyington JC, Chuang GY, Diwanji D, Georgiev I, Kwon YD, Lee D, Louder MK, Moquin S, Schmidt SD, Yang ZY, Bonsignori M, Crump JA, Kapiga SH, Sam NE, Haynes BF, Burton DR, Koff WC, Walker LM, Phogat S, Wyatt R, Orwenyo J, Wang LX, Arthos J, Bewley CA, Mascola JR, Nabel GJ, Schief WR, Ward AB, Wilson IA, Kwong PD. 2011. Structure of HIV-1 gp120 V1/V2 domain with broadly neutralizing antibody PG9. Nature, 480: 336-343.

Minor PD. 2015. Live attenuated vaccines: Historical successes and current challenges. Virology, 479-480: 379-392.

Morelli L, Poletti L, Lay L. 2011. Carbohydrates and Immunology: Synthetic Oligosaccharide Antigens for Vaccine Formulation. Eur J Org Chem, 2011: 5723-5777.

Moulard M, Decroly E. 2000. Maturation of HIV envelope glycoprotein precursors by cellular endoproteases. Biochimica et Biophysica Acta: 121-132.

Ni J, Song H, Wang Y, Stamatos NM, Wang LX. 2006. Toward a carbohydrate-based HIV-1 vaccine: synthesis and immunological studies of oligomannose-containing glycoconjugates. Bioconjug Chem, 17: 493-500.

Nikolaev AV, Sizova OV. 2011. Synthetic neoglycoconjugates of cell-surface phosphoglycans of Leishmania as potential antiparasite carbohydrate vaccines. Biochemistry(Mosc), 76: 761-773.

Pancera M, Shahzad-Ul-Hussan S, Doria-Rose NA, McLellan JS, Bailer RT, Dai K, Loesgen S, Louder MK, Staupe RP, Yang Y, Zhang B, Parks R, Eudailey J, Lloyd KE, Blinn J, Alam SM, Haynes BF, Amin MN, Wang LX, Burton DR, Koff WC, Nabel GJ, Mascola JR, Bewley CA, Kwong PD. 2013. Structural basis for diverse $\mathrm{N}$-glycan recognition by HIV-1-neutralizing V1-V2-directed antibody PG16. Nat Struct Mol Biol, 20: 804-813. 
Pejchal R, Doores KJ, Walker LM, Khayat R, Huang PS, Wang SK, Stanfield RL, Julien JP, Ramos A, Crispin M, Depetris R, Katpally U, Marozsan A, Cupo A, Maloveste S, Liu Y, McBride R, Ito Y, Sanders RW, Ogohara C, Paulson JC, Feizi T, Scanlan CN, Wong CH, Moore JP, Olson WC, Ward AB, Poignard P, Schief WR, Burton DR, Wilson IA. 2011. A potent and broad neutralizing antibody recognizes and penetrates the HIV glycan shield. Science, 334: 1097-1103.

Peri F. 2013. Clustered carbohydrates in synthetic vaccines. Chem Soc Rev, 42: 4543-4556.

Plante OJ, Palmacci ER, Seeberger PH. 2001. Automated solidphase synthesis of oligosaccharides. Science, 291: 1523-1527.

Qin Q, Yin Z, Bentley P, Huang X. 2014. Carbohydrate antigen delivery by water soluble copolymers as potential anti-cancer vaccines. Med Chem Commun, 5: 1126-1129.

Rodrigues AF, Soares HR, Guerreiro MR, Alves PM, Coroadinha AS. 2015. Viral vaccines and their manufacturing cell substrates: New trends and designs in modern vaccinology. Biotechnol J, 10: 1329-1344.

Roy R, Chieh Shiao T. 2011. Organic Chemistry and Immunochemical Strategies in the Design of Potent Carbohydrate-based Vaccines. CHIMIA, 65: 24-29.

Safari D, Marradi M, Chiodo F, Th Dekker HA, Shan Y, Adamo R, Oscarson S, Rijkers GT, Lahmann M, Kamerling JP, Penades S, Snippe H. 2012. Gold nanoparticles as carriers for a synthetic Streptococcus pneumoniae type 14 conjugate vaccine. Nanomedicine (Lond), 7: 651-662.

Said Hassane F, Phalipon A, Tanguy M, Guerreiro C, Belot F, Frisch B, Mulard LA, Schuber F. 2009. Rational design and immunogenicity of liposome-based diepitope constructs: application to synthetic oligosaccharides mimicking the Shigella flexneri 2a O-antigen. Vaccine, 27: 5419-5426.

Sanders RW, Venturi M, Schiffner L, Kalyanaraman R, Katinger H, Lloyd KO, Kwong PD, Moore JP. 2002. The Mannose-Dependent Epitope for Neutralizing Antibody 2G12 on Human Immunodeficiency Virus Type 1 Glycoprotein gp120. J Virol, 76: 7293-7305.

Scanlan CN, Pantophlet R, Wormald MR, Ollmann Saphire E, Stanfield R, Wilson IA, Katinger H, Dwek RA, Rudd PM, Burton DR. 2002. The Broadly Neutralizing Anti-Human Immunodeficiency Virus Type 1 Antibody 2G12 Recognizes a Cluster of $1 \rightarrow 2$ Mannose Residues on the Outer Face of gp120. J Virol, 76: 7306-7321.

Schmidt D, Schuhmacher F, Geissner A, Seeberger PH, Pfrengle F. 2015. Automated synthesis of arabinoxylan-oligosaccharides enables characterization of antibodies that recognize plant cell wall glycans. Chemistry, 21: 5709-5713.

Seeberger PH. 2015. The logic of automated glycan assembly. Acc Chem Res, 48: 1450-1463.

Seeberger PH, Werz DB. 2005. Automated synthesis of oligosaccharides as a basis for drug discovery. Nat Rev Drug Discov, 4: 751-763.

Swarts BM, Guo Z. 2009. Carbohydrate-Based Vaccines and Im- munotherapies. Hoboken: Wiley, pp. 167-193.

Temme JS, Drzyzga MG, MacPherson IS, Krauss IJ. 2013. Directed evolution of 2G12-targeted nonamannose glycoclusters by SELMA. Chemistry, 19: 17291-17295.

Temme JS, MacPherson IS, DeCourcey JF, Krauss IJ. 2014. High temperature SELMA: evolution of DNA-supported oligomannose clusters which are tightly recognized by HIV bnAb 2 G12. J Am Chem Soc, 136: 1726-1729.

Thompson P, Lakshminarayanan V, Supekar NT, Bradley JM, Cohen PA, Wolfert MA, Gendler SJ, Boons G-J. 2015. Linear synthesis and immunological properties of a fully synthetic vaccine candidate containing a sialylated MUC1 glycopeptide. Chem Commun (Camb), 51: 10214-10217.

Tongo M, Burgers WA. 2014. Challenges in the design of a T cell vaccine in the context of HIV-1 diversity. Viruses, 6: 3968 3990.

UNAIDS. 2015. Joint United Nations Programme on HIV/AIDS (UNAIDS) and World Health Organization (WHO). World AIDS day 2015 fact sheet (http://www.unaids.org/en/resources/ campaigns/HowAIDSchangedeverything/ factsheet).

Walker LM, Huber M, Doores KJ, Falkowska E, Pejchal R, Julien JP, Wang SK, Ramos A, Chan-Hui PY, Moyle M, Mitcham JL, Hammond PW, Olsen OA, Phung P, Fling S, Wong CH, Phogat S, Wrin T, Simek MD, Protocol GPI, Koff WC, Wilson IA, Burton DR, Poignard P. 2011. Broad neutralization coverage of HIV by multiple highly potent antibodies. Nature, 477 : 466-470.

Walker LM, Phogat SK, Chan-Hui PY, Wagner D, Phung P, Goss JL, Wrin T, Simek MD, Fling S, Mitcham JL, Lehrman JK, Priddy FH, Olsen OA, Frey SM, Hammond PW, Protocol GPI, Kaminsky S, Zamb T, Moyle M, Koff WC, Poignard P, Burton DR. 2009. Broad and potent neutralizing antibodies from an African donor reveal a new HIV-1 vaccine target. Science, 326: 285-289.

Wang J, Li H, Zou G, Wang LX. 2007. Novel template-assembled oligosaccharide clusters as epitope mimics for HIV-neutralizing antibody 2 G12. Design, synthesis, and antibody binding study. Org Biomol Chem, 5: 1529-1540.

Wang LX. 2006. Toward oligosaccharide- and glycopeptide-based HIV vaccines. Curr Opin Drug Disc, 9: 194-206.

Wang LX, Ni J, Singh S, Li H. 2004. Binding of high-mannosetype oligosaccharides and synthetic oligomannose clusters to human antibody 2G12: implications for HIV-1 vaccine design. Chem Biol, 11: 127-134.

Wang SK, Liang PH, Astronomo RD, Hsu TL, Hsieh SL, Burton DR, Wong CH. 2008. Targeting the carbohydrates on HIV-1: Interaction of oligomannose dendrons with human monoclonal antibody 2G12 and DC-SIGN. Proc Natl Acad Sci U S A, 105: 3690-3695.

Yang Q, Li C, Wei Y, Huang W, Wang LX. 2010. Expression, glycoform characterization, and antibody-binding of HIV-1 V3 glycopeptide domain fused with human IgG1-Fc. Bioconjug Chem, 21: 875-883. 